\title{
PENGARUH PENYEMPURNAAN SISTEM ADMINISTRASI DAN SANKSI TERHADAP PENERAPAN ANGGARAN BERBASIS KINERJA PADA PEMERINTAH PROVINSI JAMBI
}

\author{
Mustika \\ STIE Muhammadiyah Jambi \\ mustikaziah@yahoo.co.id
}

Abstrak

Penelitian ini bertujuan untuk menguji pengaruh penyempurnaan sistem administrasi dan Sanksi terhadap penyusunan anggaran berbasis kinerja baik secara simultan maupun secara parsial. Penelitian ini dilakukan terhadap 89 karyawan yang menjadi sampel dari 845 populasi yang ada di Pemerintah Provinsi Jambi. Metode penelitian yang digunakan adalah metode survei dengan menggunakan kuesioner. Data lapangan selanjutnya diolah menggunakan SPSS versi 17 jenis komputer, analisis teknik dari data yang digunakan untuk penelitian ini terdiri dari analisis statistik deskriptif yang mencakup penentuan nilai rata-rata, median, mode dan standar deviasi dan analisis statistik inferensial. yang meliputi penentuan koefisien korelasi berganda dan regresi linier berganda. Hasil penelitian ini menunjukkan bahwa penyempurnaan sistem administrasi dan sanksi secara serempak berpengaruh terhadap penyusunan anggaran berbasis kinerja. Secara parsial penyempurnaan sistem administrasi tidak berpengaruh signifikan terhadap penyusunan anggaran berbasis kinerja, sedangkan Sanksi berpengaruh signifikan terhadap penyusunan anggaran berbasis kinerja.

Kata Kunci : penyempurnaan sistem administrasi, sanksi dan penyusunan anggaran berbasis kinerja.

\section{PENDAHULUAN}

Salah satu bentuk reformasi sebagai implikasi dari adanya good governance adalah reformasi dibidang penganggaran. Perubahan dari pendekatan tradisional (traditional budgeting) ke pendekatan baru yaitu anggaran kinerja (performance budgeting). Pada anggaran tradisional, penyusunan anggaran didasari atas besarnya realisasi anggaran tahun sebelumnya, hal tersebut berakibat dengan tidak adanya perubahan yang signifikan atas anggaran baru. Sementara pada anggaran kinerja, sistem penyusunan dan pengelolaan daerah yang berorientasi pada pencapaian hasil atau kinerja. Hasil atau kinerja tersebut mencerminkan efisiensi, efektifitas pelayanan kepada publik yang berorientasi kepada kepentingan publik.

Penerapan anggaran berbasis kinerja di Provinsi Jambi tercermin melalui Rencana Pembangunan Jangka Menengah Daerah (RPJMD). Dalam dokumen tersebut telah ditetapkan program dan kegiatan beserta indikator kinerja sebagai sasaran. Bastian (2009) menyebutkan bahwa untuk menghasilkan penyelenggaraan anggaran daerah yang efektif dan efisien, tahap persiapan/perencanaan anggaran merupakan salah satu faktor penting dan menentukan dalam keseluruhan siklus anggaran. Pentingnya anggaran berbasis kinerja bagi pemerintah adalah untuk mendorong setiap satuan kerja agar lebih selektif dalam merencanakan aktifitas 
berdasarkan skala prioritas daerah, tugas pokok dan fungsi serta tujuan dan sasaran. Untuk itu studi mengenai anggaran berbasis kinerja serta faktor-faktor penunjangnya diperlukan sebagai upaya dalam menentukan kebijakan terkait keberhasilan implementasi anggaran berbasis kinerja.

Penyempurnaan administrasi merupakan penyajian instrumen pengukuran anggaran berbasis kinerja secara terus menerus (Sembiring, 2009). Menurut Bastian (2006), penyusunan anggaran berbasis kinerja membutuhkan suatu sistem administrasi publik yang ditata dengan baik, konsisten dan terukur sehingga kinerja anggaran dapat dicapai berdasarkan ukuranukuran yang telah ditetapkan. Hubungan antara penyempurnaan administrasi dari hasil penelitian Sembiring (2009) mengemukakan bahwa penyempurnaan admnistrasi berpengaruh signifikan terhadap anggaran berbasis kinerja.

Sanksi (punishment) juga digunakan sebagai faktor pemicu dalam mencapai anggaran berbasis kinerja. Pemberian sanksi terhadap SKPD yang tidak menerpkan anggaran berbasis kinerja dengan baik, akan memacu organisasi untuk memperbaiki kelemahan-kelemahan yang ada. Hubungan sanksi dengan anggaran berbasis kinerja pada penelitian Pradana (2014) menunjukan bahwa sanksi berpengaruh signifikan terhadap anggaran berbasis kinerja. Penelitian Fitri (2013) menunjukan bahwa sanksi tidak berpengaruh signifikan terhadap anggaran berbasis kinerja. Sedangkan Sembiring (2009) menunjukan bahwa sanksi berpengaruh signifikan terhadap anggaran berbasis kinerja.

Dalam pelaksanaannya, penganggaran berbasis kinerja masih terdapat kendala-kendala yang dihadapi. Meskipun pemerintah telah memiliki RKP yang merupakan usulan program dan kegiatan yang disertai dengan indikator-indikator, namun masih juga terdapat indikator kinerja yang kurang spesifik dan terukur. Dalam penilaian kinerja yang dilakukan melalui Laporan Akuntabilitas Kinerja Instansi Pemerintah, Tahun 2016 Provinsi Jambi masih mendapatkan predikat CC (cukup baik). Predikat tersebut menunjukan belum optimalnya tingkat akuntabilitas atau pertanggungjawaban atas hasil (outcome) terhadap penggunaan anggaran dalam rangka terwujudnya pemerintahan yang berorientasi terhadap hasil. Evaluasi yang dilakukan oleh Kemenpan RI terhadap akuntabilitas instansi pemerintah menetapkan Provinsi Jambi pada peringkat 26 dari 34 Provinsi di Indonesia. Jika dibandingkan dengan Provinsiprovinsi di Sumatera, Provinsi Jambi berada di peringkat 2 terbawah di atas Provinsi Lampung, sementara 3 provinsi di Sumatera berada pada peringkat 10 besar yaitu Provinsi Sumatera Selatan yang berada diperingkat 6, Provinsi Sumatera Barat di Peringkat 8 dan Provinsi 
Kepulauan Riau di peringkat 10. Perkembangan nilai Akuntabilitas Kinerja Instansi Pemerintah Provinsi Jambi dapat dilihat pada 5 tahun terakhir yaitu pada tahun 2013 kinerja 44,71 predikat C (agak kurang), tahun 2014 kinerja 50,95 predikat CC, tahun 2015 kinerja 56,71 predikat CC, tahun 2016 kinerja 59,36 predikat CC dan tahun 2017 kinerja 52,87 predikat CC. (Sumber : Laporan Kinerja Pemerintah Provinsi Jambi). Dari data diatas terlihat bahwa nilai akuntabilitas kinerja pemerintah Provinsi Jambi menunjukkan peningkatan dari predikat C (agak kurang) pada tahun 2013 hingga menjadi predikat CC (cukup baik) pada tahun 2014, namun dari tahun 2014 sampai 2017 tidak terjadi peningkatan. Jika dilihat dari target yang ditetapkan yaitu mendapatkan predikat B, maka Pemerintah Provinsi Jambi perlu menganalisa faktor-faktor pendukung dalam upaya meningkatkan penganggaran berbasis kinerja. Tujuan dari penelitian ini adalah; (1) menganalisis bagaimana penyempurnaan sistem administrasi dan sanksi berpengaruh terhadap penerapan anggaran berbasis kinerja secara simultan, (2) menganalisis pengaruh penyempurnaan sistem administrasi dan sanksi terhadap penerapan anggaran berbasis kinerja secara parsial.

\section{METODE PENELITIAN}

\section{A. Jenis dan Sumber Data}

Data yang akan digunakan dalam penelitian ini adalah data primer, yaitu sumber data penelitian yang diperoleh secara langsung dari sumber asli (tidak melalui media perantara). Data primer secara khusus dikumpulkan oleh peneliti untuk menjawab pertanyaan penelitian.

\section{B. Populasi dan Sampel}

Populasi adalah wilayah generalisasi yang terdiri dari obyek/subyek yang mempunyai kualitas dan karakteristik tertentu yang ditetapkan oleh peneliti untuk dipelajari dan kemudian ditarik kesimpulannya (Sugiyono, 2012). Populasi dalam penelitian ini adalah para pejabat struktural pada SKPD di lingkungan Pemerintah Provinsi Jambi yang menduduki jabatan sebagai kepala dinas, kepala bagian, kepala sub bagian, kepala sub bidang dan kepala seksi. Populasi pada penelitian ini adalah sebagai berikut:

Berdasarkan Sumber Badan Kepegawaian Daerah Provinsi Jambi Tahun 2017 dapat diketahui bahwa jumlah seluruh pejabat struktural sebanyak 845 orang, terdiri dari 1 orang pejabat eselon I, 55 orang pejabat eselon II, 219 orang pejabat eselon III dan 570 orang pejabat eselon IV. Eselon I tidak digunakan sebagai responden dengan alasan adanya hambatan dan kesulitan dalam memeperoleh informasi serta berkomunikasi dengan pejabat yang bersangkutan. 
Sampel adalah bagian dari jumlah dan karakteristik yang dimiliki oleh populasi tersebut (Sugiyono, 2012). Dari Populasi data diatas didapat kan sampel sebanyak 89 orang dengan menggunakan rumus Proportionate Startified Random Sampling.

\section{C.Metode Analisis Data}

\section{1) Analisis Regresi Berganda}

Penelitian ini menggunakan analisis regresi linear berganda. Adapun persamaannya yaitu sebagai berikut: $\mathrm{Y}=\beta 0+\beta 1 \mathrm{X} 1+\beta 2 \mathrm{X} 2+\mathrm{e}$

Keterangan:

$\mathrm{Y} \quad=$ Penerapan Anggaran Berbasis Kinerja

B0 $=$ Konstansta

$\beta 1, \beta 2, \beta 3=$ Koefisien regresi

$\mathrm{X} 1=$ penyempurnaa sistem administrasi

$\mathrm{X} 2=$ Sanksi

$\mathrm{E} \quad=$ error

\section{2) Uji Simultan (Uji F)}

Untuk menjawab rumusan masalah nomor 1 digunakan Uji F. Uji F dilakukan untuk mengetahui apakah semua variabel independen secara bersama-sama berpengaruh terhadap variable dependen.

\section{3) Uji Parsial (Uji t)}

Untuk menjawab rumusan masalah nomor 2 digunakan Uji t. Uji t dilakukan untuk mengetahui apakah masing-masing variabel independen secara parsial berpengaruh terhadap variabel dependen.

\section{4) Koefisien Determinasi (R2)}

Koefisien determinasi digunakan untuk mengetahui besarnya pengaruh variabel independen terhadap variabel dependen, jika $\mathrm{R} 2=100 \%$ berarti variabel independen berpengaruh sempurna terhadap variabel dependen. Nilai R2 yang semakin tinggi menjelaskan bahwa semakin cocok variabel independen menjelaskan/ menentukan variabel dependen. Semakin kecil nilai R2 berarti semakin sedikit kemampuan variabel-variabel independen untuk menjelaskan/ menentukan variabel dependen (Ghozali, 2011). 


\section{HASIL PEMBAHASAN}

\section{1) Karakteristik Responden}

Responden dalam penelitian ini adalah Para Pejabat Struktural di Satuan Kerja Perangkat Daerah pada Pemerintah Provinsi Jambi yang terdiri dari Eselon II, III dan IV. Dari 100 kuisioner yang disebar, terhimpun pengembaliannya sebanyak 95 kuisioner dan 6 kuisioner diantaranya digugurkan karena tidak lengkap pengisiannya. Sehingga secara keseluruhan yang layak digunakan untuk analisis selanjutnya adalah 89 kuisioner atau $89 \%$. Berikut karakteristik responden yang dihitung berdasarkan jenis kelamin, pendidikan terakhir, latar belakang pendidikan, jabatan dan lama bekerja.

\section{2) Pengujian Hipotesis}

\section{A. Pengujian Simultan ( Uji -F)}

Tabel 1

Hasil Pengujian Simultan (Uji F)

\begin{tabular}{|c|c|c|}
\hline Keterangan & F & Sig. \\
\hline Hasil Regresi & 21.303 & 0.000 \\
\hline
\end{tabular}

Pengaruh penyempurnaan sistem administrasi dan sanksi terhadap penerapan anggaran berbasis kinejra secara simultan Sumber: Hasil Pengolahan Data, 2018

Menentukan Ho dan Ha:

Ho:b1,2,3 = 0 (tidak terdapat penyempurnaan sistem administrasi dan sanksi, terhadap penerapan anggaran berbasis kinejra)

$>\mathrm{H} 1: \mathrm{b} 1,2,3, \neq 0$ (terdapat pengaruh variabel penyempurnaan sistem administrasi dan sanksi terhadap penerapan anggaran berbasis kinejra).

Ho diterima jika F hitung < 2,211 dan Ha ditolak jika F hitung $>2,211$.

Berdasakan hasil perhitungan di atas, diketahui nilai $\mathrm{F}$ hitung $=21,303$ dan signifikansi $=0,000$ atau $0 \%$. Diperoleh perbandingan $\mathrm{F}$ hitung $=21,303>\mathrm{F}$ tabel $=2,211$ atau signifikansi $=0 \%$ $\square$ alpha $=5 \%$, maka Ho ditolak berarti terdapat pengaruh variabel penyempurnaan sistem administrasi dan sanksi, terhadap penerapan anggaran berbasis kinerja. Hal tersebut menunjukan bahwa jika penyempurnaan sistem administrasi dan sanksi semakin membaik maka penerapan anggaran berbasis kinerja juga akan semakin membaik, dengan demikian hipotesis 1 diterima 


\section{B. Pengujian Secara Parsial ( Uji -t)}

Pengujian secara parsial dilakukan untuk menentukan apakah setiap variabel berpengaruh terhadap penerapan anggaran berbsis kinerja pada Pemerintah Provinsi Jambi secara parsial.

Tabel 2. Hasil Regresi Linear (Uji t)

\begin{tabular}{|l|l|l|l|}
\hline Keterangan & $\begin{array}{l}\text { Unstandardized } \\
\text { Coefficient (B) }\end{array}$ & t hitung & Signifikansi \\
\hline $\begin{array}{l}\text { Konstanta } \\
\text { Administrasi }\end{array}$ & -0.066 & -0.284 & 0.835 \\
\hline Sanksi & 0.184 & 1.611 & 0.111 \\
\hline
\end{tabular}

Sumber: Hasil Pengolahan Data, 2018

a. Pengaruh penyempurnaan sistem administrasi terhadap penerapan anggaran berbasis kinerja Ho diterima jika t hitung berada diantara -1,664 dan + 1,664 dan Ho ditolak jika t hitung < $-1,664$ atau t hitung $>1,664$. Hasil perhitungan berdasarkan tabel 4.22 diatas diketahui nilai t hitung variabel penyempurnaan sistem administrasi sebesar 1,611 dan signifikansi $=$ 0,111 atau $11,1 \%$. Diperoleh perbandingan $\mathrm{t}$ hitung $=1,611<\mathrm{t}$ tabel $=1,664$ atau nilai signifikansi $11,1 \%>$ alpha $=5 \%$, maka Ho diterima berarti penyempurnaan sistem administrasi tidak berpengaruh terhadap penerapan anggaran berbasis kinerja pada Pemerintah Provinsi Jambi.

b. Pengaruh sanksi terhadap penerapan anggaran berbasis kinerja.

Ho diterima jika $t$ hitung berada diantara $-1,664$ dan $+1,664$ dan Ho ditolak jika t hitung $<-1,664$ atau $t$ hitung $>1,664$. Hasil perhitungan berdasarkan tabel 4.22 diatas diketahui nilai $\mathrm{t}$ hitung variabel sanksi sebesar 2,542 dan signifikansi $=0,013$ atau 1,3\%. Diperoleh perbandingan $\mathrm{t}$ hitung $=2,542>\mathrm{t}$ tabel $=1,664$ atau nilai signifikansi $=1,3 \%$ $<$ alpha $=5 \%$, maka Ho ditolak berarti sanksi berpengaruh terhadap penerapan anggaran berbasis kinerja.

\section{Koefisien Determinan (R2)}

Koefisiensi determinasi (R2) digunakan untuk mengukur seberapa besar pengaruh variabel bebas. Uji koefisien determinasi (R2) adalah dengan persentasi pengkuadratan nilai koefisien yang ditemukan. Koefisien determinan (R2) berkisar antara 0 (nol) sampai dengan 1 (satu), (0 $\leq \mathrm{R} 2 \leq 1)$. Hal ini berarti bila R2 semakin tinggi (mendekati satu), maka dapat dikatakan bahwa variabel bebas $(\mathrm{X} 1, \mathrm{X} 2)$ memiliki pengaruh yang besar terhadap variabel terikat (Y). Hasil koefisien determinan (R2) dapat dilihat pada tabel berikut : 
Tabel 3. Koefesien Determinasi $\left(\mathbf{R}^{2}\right)$

\begin{tabular}{|c|c|c|c|}
\hline Keterangan & $\mathrm{R}$ & R Square & Adjusted R Square \\
\hline & & & \\
\hline Hasil regresi & $0.772^{\mathrm{a}}$ & 0.596 & 0.567 \\
\hline
\end{tabular}

Sumber: Hasil Pengolahan Data, 2018

Berdasarkan tabel di atas, dapat dilihat bahwa nilai $\mathrm{R}$ square yang diperoleh sebesar 0,567, nilai tersebut menunjukan bahwa besar pengaruh variabel independen yaitu penyempurnaan sistem administrasi dan sanksi terhadap penerapan anggaran berbasis kinerja yang dapat dijelaskan oleh model persamaan ini adalah sebesar 56,7\%, dan sisanya 43,3\% dipengaruhi oleh faktor-faktor lain yang tidak dimasukkan dalam model regresi.

\section{A. Pengaruh Penyempurnaan Sistem Administrasi (X1), Sanksi (X2), Terhadap Penerapan Anggaran Berbasis Kinerja (Y)}

Uji secara bersama-sama yang dilakukan pada variabel penyempurnaan sistem administrasi dan sanksi, terhadap anggaran berbasis kinerja pada SKPD di Pemerintah Provinsi Jambi menunjukan hasil yang signifikan. Hal tersebut menunjukan bahwa semakin baik penyempurnaan sistem administrasi dan sanksi maka penerapan anggaran berbasis kinerja pada Pemerintah Provinsi Jambi juga akan semakin membaik.

Hasil penelitian ini mendukung penelitian Sembiring (2009) yang menyatakan bahwa terdapat pengaruh signifikan antara komitmen dari seluruh komponen organisasi, penyempurnaan sistem administrasi, sumber daya yang cukup, penghargaan yang jelas serta sanksi yang tegas terhadap APBD berbasis kinerja. Hal tersebut juga sesuai dengan yang diungkapkan BPKP (2005) bahwa ada faktor pemicu keberhasilan implementasi anggaran berbasis kinerja yaitu (a) kepemimpinan dan komitmen dari seluruh komponen organisasi; (b) fokus penyempurnaan sistem administrasi secara terus-menerus; (c) sumber daya yang cukup untuk usaha penyempurnaan tersebut (uang, waktu, dan orang); (d) penghargaan (reward) dan sanksi (punishment); dan (e) keinginan yang kuat untuk berhasil.

\section{B. Pengaruh Penyempurnaan Sistem Administrasi (X1) Terhadap Penerapan Anggaran Berbasis Kinerja (Y)}

Berdasarkan hasil uji parsial yang telah dilakukan, tidak terdapat pengaruh antara penyempurnaan sistem administrasi sebagai variabel $\mathrm{X} 1$ terhadap penerapan anggaran berbasis kinerja sebagai variabel Y. Hasil penelitian ini sejalan dengan penelitian Iratni et al (2012) yang menunjukkan penyempurnaan sistem informasi tidak berpengaruh terhadap penerapan anggaran berbasis kinerja yang berarti bahwa 
penyempurnaan sistem informasi memiliki peranan yang kurang penting dalam mensukseskan penerapan anggaran berbasis kinerja.

Berdasarkan hasil observasi terhadap penyempurnaan sistem administrasi menunjukan bahwa sistem administrasi terkait penganggaran berbasis kinerja belum berjalan dengan optimal. Dokumen-dokumen perencanaan yang seharusnya dimiliki oleh staf penyusun anggaran belum terakomodir dengan baik, sehingga penyusunan anggaran seringkali berdasarkan atas apa yang diajukan/diusulkan oleh bagian masing-masing tanpa membandingkan dengan dokumen perencanaan yang telah disusun sebelumnya. Selain itu evaluasi atas pelaksanaan kinerja tahun-tahun sebelumnya juga tidak tersusun dengan baik, hal ini jelas berpengaruh terhadap pengambilan keputusan terkait keberhasilan program dan kegiatan yang akan datang. Diperlukan suatu sitem berkelanjutan (komputerisasi) yang dapat diakses oleh pemangku-pemangku kepentingan terkait penyusunan anggaran berbasis kinerja.

Evaluasi atas Akuntabilitas Kinerja Instansi Pemerintah menyebutkan bahwa belum terbangun pemantauan dan pengendalian kinerja secara berkelanjutan pada level provinsi maupun SKPD. Pemantauan capaian kinerja menggunakan cara-cara manual sehingga cukup menyulitkan pimpinan untuk mendapatkan gambaran utuh atas capaian kinerja yang telah diperjanjikan.

\section{Pengaruh Sanksi (X2) Terhadap Penerapan Anggaran Berbasis Kinerja (Y)}

Berdasarkan hasil uji parsial yang telah dilakukan terdapat pengaruh positif antara sanksi sebagai variabel X6 terhadap penerapan anggaran berbasis kinerja sebagai variabel Y. Hasil penelitian ini sejalan dengan penelitian Sembirng (2009) yang menyebutkan bahwa terdapat pengaruh positif dan signifikan variabel sanksi terhadap anggaran berbasis kinerja. Penelitian Iratni et al (2012) juga menunjukkan adanya pengaruh sanksi terhadap penerapan anggaran berbasis kinerja yang berarti bahwa dampak sanksi sejalan dengan penerapan anggaran berbasis kinerja atau dengan kata lain sanksi yang tinggi akan mempengaruhi suksesnya penerapan anggaran berbasis kinerja dan begitu pula sebaliknya.

Pemberian sanksi (punishment) sebagai salah faktor pemicu keberhasilan implementasi anggaran berbasis kinerja juga memegang peranan penting. Dalam menjalankan organisasi diperlukan sebuah aturan dan hukum yang berfungsi sebagai alat pengendali agar kinerja pada organisasi tersebut dapat berjalan dengan baik (Fitri, 2013). Berdasarkan hasil observasi terhadap sanksi menunjukan bahwa sanksi yang diberikan terkait penyusunan 
anggaran berbasis telah diterapkan oleh Bappeda maupun BPKAD. Hasil penelitian ini mengindikasikan bahwa apabila SKPD terlambat dalam melakukan penyusunan anggaran akan mendapatkan sanksi berupa penundaan penetapan anggaran SKPD-nya. Selain itu, dokumen perencanaan maupun dokumen anggaran tidak akan ditindak lanjuti tanpa adanya indikator kinerja yang jelas dan terukur atas program dan kegiatan yang dilaksanakan oleh tiap-tiap SKPD.

\section{KESIMPULAN}

1. Penyempurnaan Sistem Administrasi, Sanksi, secara keseluruhan merupakan faktor yang menentukan penerapan anggaran berbasis kinerja pada Pemerintah Provinsi Jambi.

2. Pengaruh variabel independen terhadap variabel dependen dapat dijelaskan sebagai berikut:

A. Penyempurnaan Sistem Administrasi tidak termasuk faktor yang menentukan penerapan anggaran berbasis kinerja pada Pemerintah Provinsi Jambi.

B. Sanksi merupakan faktor yang menentukan penerapan anggaran berbasis kinerja pada Pemerintah Provinsi Jambi.

\section{DAFTAR PUSTAKA}

Bastian,I.,2006, Akuntansi Sektor Publik, Erlangga, Jakarta.

2009, Sistem Perencanaan dan Penganggaran Pemerintah Daerah di Indonesia, Salemba Empat, Jakarta.

Fitri, S.M., dkk, 2013, Pengaruh Gaya Kepmimpinan, Komitmen Organisasi, Kualitas Sumber Daya, Reward dan Punishment terhadap Anggaran Berbasis Kinerja, Jurnal Dinamika Bangsa.

Ghozali, I., 2011, Aplikasi Analisis Multivariate dengan Program SPSS, BP Universitas Diponegoro, Semarang.

Nawawi, H., dkk, 2006, Kepemimpinan yang Efektif, UGM Press, Yogyakarta.

Pradana, B.A., dkk, 2014, Determinasi Implementasi Anggaran Berbasis Kinerja Badan Layanan Umum (Pada Universitas Negeri Semarang), Accounting Analisis Journal.

Sembiring, B.B., 2009, Faktor-Faktor Yang Mempengaruhi Penyusunan Anggaran Pendapatan Dan Belanja Daerah Berbasis Kinerja (Studi Empiris di Pemerintah Kabupaten Karo), Tesis.

Soleh, A., Putra, I. E., \& Rahayu, Y. (2017). ANALISIS KINERJA APARATUR DAN PELAYANAN PUBLIK SEBAGAI DASAR MENUJU REFORMASI BIROKRASI YANG IDEAL. Jurnal Development, 5(2), 110-124. 
Windayani, S., 2008, Analisis Faktor-Faktor yang Berpengaruh Terhadap Penggunaan Informasi Kinerja Dalam Penganggaran, Jurnal Ekonomi dan Bisnis.

Syafiie, I.K, 2009, Sistem Administrasi Negara Republik Indonesia, PT Bumi Aksara, Jakarta.

Siagian, S.,1986, Administrasi Pembangunan, PT Bumi Aksara, Jakarta.

Sugiyono, 2012, Metode Penelitian Bisnis, Alfabeta, Bandung.

Undang-Undang Nomor 22 Tahun 1999 diperbaharui menjadi Undang-Undang Nomor 23 Tahun 2014 tentang Pemerintahan Daerah.

Undang-Undang Nomor 25 Tahun 1999 diperbaharui menjadi Undang-Undang Nomor 33 Tahun 2004 tentang Perimbangan Keuangan Pemerintah Pusat dan Daerah.

Undang-Undang Nomor 17 Tahun 2003 tentang Keuangan Negara.

Peraturan Pemerintah Nomor 20 Tahun 2004 tentang Rencana Kerja Pemerintah.

Peraturan Pemerintah Nomor 21 Tahun 2004 tentang Penyusunan Rencana Kerja dan Anggaran Kementerian/Lembaga (RKA-KL). 